\title{
Dakwah Bil-Hikmah: Membangun Etos Kerja Islami Dalam Masyarakat Priyayi Jawa \\ (Analisis Pegawai Pemerintahan Kelurahan Bangetayu Kulon, Kecamatan Genuk)
}

\author{
Ulfatun Hasanah \\ Jurusan Komunikasi Penyiaran Islam, Fakultas Dakwah dan Komunikasi \\ Universitas Islam Negeri Walisongo, 50185, Indonesia \\ ulfatunhasanah92@gmail.com
}

Riwayat Artikel:

Diterima Desember 2017

Direvisi Januari 2018

Disetujui Februari 2018
Kata Kunci:

Dakwah, Bil-Hikmah,

Budaya,

Etos Kerja Islami,

Priyayi Jawa

Keywords:

Da'wah, Bil-Hikmah,

Culture,

Islamic Work Ethos,

Java Priyayi

\begin{abstract}
Abstrak: Dakwah adalah bagian yang pasti ada dalam kehidupan umat beragama. Salah satu ajaran Islam, dakwah merupakan kewajiban yang dibebankan agama kepada pemeluknya. Dakwah intinya mengajak kepada kebaikan (amar makruf). Salah satu metode dakwah yang dipakai adalah dakwah bil-hikmah. Dakwah bilhikmah berarti dakwah bijak, dengan memperhatikan kadar pemikiran dan intelektual, suasana psikologis, serta situasi sosial kultural mad'u. Sebagaimana yang dikemukakan oleh Clifford Geertz dengan tiga varian, santri, abangan, dan priyayi. Mula-mula, priyayi adalah mereka yang memiliki garis keturunan dengan raja atau adipati (dalam bahasa Jawa, priyayi adalah para yayi atau para adik raja), namun dengan perkembangan zaman lahirlah priyayi baru. Tujuan penelitian untuk melihat gambaran dakwah bil-hikmah: membangun etos kerja Islami dalam masyarakat priyayi, penelitian pada pegawai pemerintahan di Kelurahan Bangetayu Kulon, Kecamatan Genuk. Dengan adanya etos kerja Islami pada masyarakat priyayi di Kelurahan Bangetayu Kulon, Kecamatan Genuk diharapkan dapat berdampak positif terhadap kinerja pegawai pemerintahan. Selain itu, hasil penelitian ini diharapkann juga mendapatkan gambaran model dakwah yang lebih inovatif untuk masyarakat priyayi Jawa.
\end{abstract}

Abstract : Da'wah is something that must exist in the life of religious people. One of the teachings of Islam, da'wah is a duty that is charged to the followers of islam. Its main mission invites people do good things (amar makruf). One of the da'wah method used is da'wah bil-hikmah (da'wah wisdomly). Da'wah bil-hikmah means dakwah full of wisdom, with attention to the level of thought and intellectual, psychological aura, and cultural social situation of mad'u (listener). As Clifford Geertz puts it with three variants, santri, abangan, and priyayi. Firstly, priyayi are those who have a lineage with Kings or Dukes (in Javanese, priyayi are Yayis or sibling of Kings), but with the era development, new priyayi appears. So, the purpose of the research is to see the description of da'wah bil-hikmah: to build islamic work ethos in priyayi society, research on government officials in Bangetayu Kulon District, Genuk Sub-district. With the Islamic work ethos in the priyayi community in Bangetayu Kulon district, Genuk District is expected to have a positive impact on the performance of government employees. In addition, the results of this study are expected to also get more innovative model of dakwah for the Javanese priyayi society.

\section{Pendahuluan}

Islam merupakan sistem kehidupan yang sempurna (a complete way of life) karena mengandung prinsip-prinsip yang fundamental dalam mengatur segala aspek 
kehidupan manusia. ${ }^{1}$ Kesempurnaan agama Islam ini hendaknya juga diikuti dengan implementasi ajarannya secara menyeluruh sebagaimana firman Allah SWT dalam Al-Quran surat Al-Baqaarah ayat $208 .^{2}$

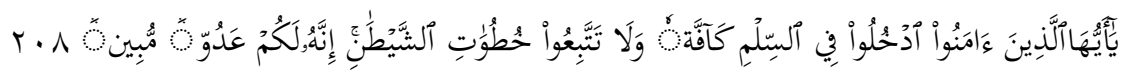

Artinya: "Hai orang-orang yang beriman, masuklah kamu ke dalam Islam keseluruhan, dan janganlah kamu turut langkah-langkah syaitan. Sesungguhnya syaitan itu musuh yang nyata bagimu." (QS. Al-Baqarah: 208)

Salah satu implementasi dari ajaran agama Islam adalah bekerja. Bekerja mempunyai arti penting bagi manusia, bekerja bertujuan untuk mendapatkan ridho dari Allah SWT. Karena hal tersebut merupakan bentuk ibadah manusia kepada Allah SWT dan menjadi bagian yang tidak terpisahkan dari karakteristik sikap hidup orang yang memeluk agama Islam.

Rasulullah SAW menyeru umatnya untuk bekerja, ${ }^{3}$ entah itu sebagai pedagang, petani atau yang lain dan tidak menghendaki seorang muslim hanya beribadah saja, berdiam diri, dan hanya menunggu rezeki yang telah dijanjikan oleh Allah SWT. Bekerja keras merupakan kewajiban bagi manusia di muka bumi ini, Rasulullah SAW bersama sahabat-sahabatnya telah banyak memberikan pelajaran tentang memiliki etos kerja yang luar biasa ketika bekerja. Seorang muslim dalam bekerja harus mempunyai semangat atau etos kerja khususnya secara Islami.

Oleh karena itu, perlunya dakwah bil-hikmah dalam membangun etos kerja Islami pada masyarakat priyayi Jawa. Menurut antropolog Clifford Geertz masyarakat muslim Jawa terdiri dari berbagai varian yaitu santri, abangan, dan priyayi. Tiga varian tersebut memiliki latar belakang yang berbeda. ${ }^{4}$ Priyayi adalah mereka yang memiliki garis keturunan dengan raja atau adipati (dalam bahasa Jawa, priyayi adalah para yayi atau para adik raja). Akan tetapi dengan semakin terdidiknya masyarakat biasa dan keberhasilan mereka memperoleh karir di berbagai bidang di pemerintahan, maka priyayi tidak harus memiliki darah bangsawan, sering disebut priyayi baru. Salah satu, masyarakat priyayi baru pada pegawai pemerintahan Kelurahan Bangetayu Kulon, Kecamatan Genuk. Selanjutnya bagaimana berdakwah bil-hikmah pada masyarakat priyayi Jawauntuk membangun etos kerja islami?

\section{Kajian Pustaka}

\section{A. Tinjauan Tentang Masyarakat Priyayi Jawa}

Priyayi berasal dari kata para yayi (para adik), yang dimaksud adik dari raja, maksudnya adalah para adik raja yaitu status kedudukanya berada di bawah raja tentunya dalam hal ini priyayi memiliki kewibawaan, kehormatan yang tinggi serta dekat dengan pejabat tinggi. ${ }^{5}$ Demikianlah kata itu diterangkan oleh masyarakat Jawa melalui jawa dhosok ${ }^{6}$.

Pada awal munculnya kalangan Priyayi yang oleh Geertz diasumsikan sebagai kaum elit atau golongan bangsawan yang menduduki posisi penting di pemerintahan. Golongan Priyayi awalnya hanya diistilahkan bagi kalangan aristokrasi turun temurun yang oleh Belanda diambil dengan mudah dari raja-raja Jawa yang ditaklukkan untuk kemudian diangkat sebagai pejabat sipil yang digaji. Elit pegawai ini, yang ujung akar-akarnya terletak pada kraton Hindu-Jawa sebelum masa kolonial, memelihara dan mengembangkan etiket kraton yang sangat halus, kesenian yang sangat komleks dalam tarian, sandiwara, musik, sastra, dan mistisme Hindu-Budha.

\footnotetext{
${ }^{1}$ Arie Mooduto. Ekonomi Islam: Pilihan Mutlak Seorang Muslim. (Jakarta:-, 2012), 42.

${ }^{2}$ Departemen Agama Republik Indonesia. Al-Qur'an dan Terjemahannya. (Jakarta: Karya Insan Indonesia, 2002).

${ }^{3}$ Freddy Rangkuti, Keajaiban Teknik Selling Rasulullah, (Jakarta: Gramedia Pustaka Utama, 2012), 4.

${ }^{4}$ Mahendra Dwi Satrio Nugroho, dkk, " Makna Pemakaian Gelar Kebangsawanan Jawa (Sebuah Interpretative Phenomenological Analysis)", Jurnal Empati, Agustus 2016, Volume 5(3), hlm. 1-2.

${ }^{5}$ Savitri Scherer, Keselarasan \& Kejanggalan (Pemikiran-Pemikiran Priyayi Nasionalis Jawa Awal Abad XX), (Jakarta: Komunitas Bambu, 2012), 7).

${ }^{6}$ Sartono Kartodirdjo, dkk, Perkembangan Peradaban Priyayi, (Yogyakarta: Gadjah Mada University Press, 1987 ), 3-4.
} 
Status bangsawan adalah status kelas atas sehingga dipandang mulia dan terhormat. Untuk memelihara keningratan ini, kerajaan mengamankan status ini sebagai status yang hanya dapat diwariskan karena keturunan atau perkawinan sehingga awalnya priyayi murni sebagai status yang diwariskan (ascribed status) bukan status yang diperoleh lewat usaha tertentu (achieved status).

Sebagai bagian dari tipologi keagamaan dalam masyarakat Jawa, kaum Priyayi tentu saja sangat dipengaruhi oleh kehidupan aristokrasi pada masa kolonial. Sementara titik utama orientasi kehidupan keagamaan kaum Priyayi adalah etiket seni dan praktik mistis yang bercorak Hinduisme. Tidak heran bila mereka tidak menekankan pada elemen animistis dari sinkretisme Jawa yang serba melingkupi seperti kaum Abangan, tidak pula menekankan pada elemen Islam sebagaimana kaum Santri, tetapi menitikberatkan pada elemen Hinduisme. Corak yang demikian tidak bisa dilepaskan dari pola kehidupan kaum Priyayi, yang secara langsung berafisiliasi dengan struktur sosial yang termasuk golongan pegawai birokrasi.

Pengaruh kultur keraton juga sangat kuat seiring dengan berbaurnya kelompok ini dengan rajaraja pribumi yang waktu itu dibayang-bayangi oleh penjajahan Belanda. Varian ini menunjuk pada elemen Hinduisme lanjutan dari tradisi Keraton Hindu-Jawa yang menguasai pemerintahan. Sebagaimana halnya keraton (simbol pemerintahan birokratis), maka priyayi lebih menekankan pada kekuatan sopan santun yang halus, seni tinggi, dan mistisisme intuitif dan potensi sosialnya yang memenuhi kebutuhan kolonial Belanda untuk mengisi birokrasi pemerintahannya. Secara tidak langsung kaum Priyayi telah berafiliasi dengan kolonial Belanda, karena mereka banyak menduduki posisi strategis untuk membantu misi penjajahan. ${ }^{7}$

Situasi ini membuat mengakibatkan kultur kraton yang tradisional makin diperlemah oleh kolonial, karena kaum Priyayi dicomot dari kerajaan pribumi yang dipekerjakan sebagai instrumen adimistrasi kekuasaan kolonial. Meski demikian, varian Priyayi tidak saja tetap kuat bertahan di kalangan anasir masyarakat yang lebih konservatif, tetapi juga memainkan peranan penting dalam membentuk pandangan dunia (world view), etika dan tingkah laku sosial anasir yang bahkan paling diperberat dalam kelompok pegawai yang masih dominan itu. Tidak heran bila sikap sopan santun yang halus, seni tinggi, dan mistisme intuitif masih dianggap sebagai karakteristik utama elitjawa ini. Dan sekalipun sudah makin memudar dan mengalami adaptasi dengan keadaan yang sudah berubah, gaya hidup (life style) priyayi masih tetap jadi model tidak saja untuk kalangan elit, tapi dengan berbagai jalan juga menjadi model bagi seluruh masyarakat.

Terkait dengan kepercayaan agama di kalangan priyayi, sesungguhnya cukup beragam sesuai dengan suatu tradisi yang mewarnai varian dari sistem agama orang Jawa ini. Pertama, ada priyayi yang secara aktif melibatkan diri dalam agama Islam, yang biasa disebut dengan priyayi santri. Biasanya mereka terdiri dari atas orang-orang lanjut usia dan ketaatan mereka terhadap agama dapat diungkapkan dalam mistik atau dengan jalan menekuni tulisan-tulisan tentang Islam. Kedua, ada priyayi yang tidak begitu menghiraukan Islam, yang biasa disebut dengan priyayi abangan. Sebagian dari mereka bahkan sama sekali tidak mempedulikan agama, mereka mungkin atheis atau agnostik meskipun tidak banyak golongan yang seperti itu. Sebaliknya, ada priyayi yang disebut abangan, akan tetapi sebenarnya mereka bukanlah orang-orang yang tidak beragama. Mereka mungkin saja memeluk agama leluhur mereka yang sangat kental dengan nilai-nilai mistis. ${ }^{8}$

Terlepas dari orientasi keagamaan kaum Priyayi, varian ini juga turut membantu mengusir penjajahan dengan memberikan kesempatan kepada kaum santri untuk terlibat langsung dalam berbagai gerilya. Penyebaran Islam di Jawa bukan hanya dibantu oleh para ulama dan santri yang bermukim di pesantren, melainkan juga oleh kerajaan-kerajaan Islam yang turut serta dalam

\footnotetext{
${ }^{7}$ Bima Widiatiaga, "Resume Abangan, Santri, dan Priyayi dalam Masyarakat Jawa, Karya Clifford Geertz," dalam resume, UNS Surakarta, 2014, 3

${ }^{8}$ Ibid, hal 4.
} 
melancarkan proses islamisasi. Memang harus diakui pada masa penjajahan Belanda, proses Islamisasi tidak berjalan mudah karena selalu mendapatkan pertentangan dan hambatan langsung dari pemerintahan kolonial Belanda sehingga proses pemantapan keislaman agar menjadi muslim yang taat sedikit mengalami jalan terjal.

Sementara kalangan bangsawan dan kaum priyayi tidak banyak melakukan tindakan untuk membantu proses pemantapan ketaatan masyarakat kepada ajaran Islam, karena di samping menghadapi pembatasan, mereka juga mendapatkan ancaman dari kekuasaan Belanda yang dikenal sangat kejam terhadap kalangan rakyat jelata.

Sebagai bagian dari tipologi masyarakat Jawa, keengganan kaum priyayi untuk melakukan pemantapan keimanan terhadap ajaran Islam patut dipertanyakan, karena mereka juga merupakan kalangan Islam modern yang memiliki kedekatan dengan kekuasaan. Sejauh Islam dianggap antikolonial, kaum priyayi lebih cenderung untuk mengembangkan pola kehidupan keagamaan yang lebih bersifat kejawen daripada memilih menjadi santri.

Ketakutan Belanda kepada orang-orang yang cenderung condong kepada Islam mempengaruhi struktur dan kesempatan dalam administrasi kepegawaian pribumi. Semisal pada waktu seorang patih yang dilaporkan menghina Islam oleh Belanda kemudian dinaikkan pangkatnya menjadi bupati, maka hal ini menjadi pelajaran yang jelas bagi teman-temannya. ${ }^{9}$

Sesudah merdeka pada tahun 1945 kehidupan kepriyayian dapat dikatakan berakhir. Generasi lama dari golongan priyayi, yang menduduki jabatan-jabatan pemerintahan dan yang menjadi pengemban serta penerus norma-norma dan nilai-nilai tradisional kepriyayian, jumlahnya berangsur-angsur berkurang. Sebagai gantinya muncul generasi baru yang tidak semuanya berasal dari golongan priyayi. Generasi baru ini, yang menduduki jabatan-jabatan pemerintahan yang dahulu dapat dikatakan didominasi golongan priyayi, berusaha melestarikan gaya hidup kepriyayian demi statusnya, tetapi usaha itu hanya berhasil terbatas pada upacara-upacara. Etika dan makna hidup kepriyayian tidak dapat dimengerti dan diikuti. Generasi baru ini bukan pengemban dan penerus warisan budaya priyayi dari masa yang lalu.

Pada bukunya Kebudayaan Jawa, Kuntjaraningrat mengatakan bahwa priyayi ada dua macam, sebagai berikut: (1) priyayi pangrehpraja (priyayi lama) atau keturunan bangsawan adalah pejabat-pejabat pemerintah daerah, yaitu orang-orang yang terpenting dan yang paling tinggi gengsinya di antara priyayi lainnya, yang disebabkan karena sifat kebangsawanan mereka, (2) golongan bukan pangrehpraja (priyayi baru) atau priyayi non-bangsawan adalah golongan orangorang terpelajar, yang berasal dari daerah pedesaan atau daerah golongan tiyang alit di kota yang berhasil mencapai kedudukan pegawai negeri melalui pendidikan, seperti: priyayi dokter, priyayi guru, priyayi kehewanan, dan sebagainya. ${ }^{10}$

\section{B. Tinjauan Tentang Hubungan Dakwah Dan Budaya}

Dakwah dan budaya adalah dua hal yang tidak dapat dipisahkan. Dakwah berasal dari bahasa arab, kata $d a{ }^{\prime} a$, artinya memanggil atau menyeru, mengajak atau mengundang. Jika diubah menjadi da'watun, maka maknanya akan berubah menjadi seruan, panggilan, atau undangan.Dakwah Islamiyah adalah salah satu kegiatan penting yang wajib dilakukan oleh umat Islam. ${ }^{11}$ Berdakwah mempunyai landasan normatif yaitu al-Qur'an dan Hadis. al-Qur'an memuat banyak ayat yang berisi tentang dakwah dan prinsip-prinsip cara melaksanakannya yang diperuntukkan semua umat Islam.

\footnotetext{
${ }^{9}$ Mohammad Takdir Ilahi, “Konfigurasi Islam Nusantara: dari Islam Santri, Abangan, hingga Priyayi,” diakses pada Sabtu, 7 Mei 2016 , http : // www. Nu . or. id/ post/ read/ 67961/ konfigurasi -islam-nusantara-dari-islam-santri-abangan-hingga-priyayi.

${ }^{10}$ Sartono Kartodirdjo, dkk, Perkembangan Peradaban Priyayi, 9-25.
} 
Sedangkan kata budaya (dari kata budhi artinya akal dan daya artinya kekuatan atau dorongan) berarti kekuatan akal karena kebudayaan manusia merupakan ukuran pencurahan kekuatan manusia yang berpangkal pada akal, baik akal pikiran, akal hati maupun akal tindakan. Secara sederhana, kebudayaan adalah hasil cita, cipta, karya, dan karsa manusia yang diperoleh melalui belajar. Menurut Prof. Koentjaraningrat ${ }^{12}$, kebudayaan sebagai keseluruhan gagasan dan karya manusia yang harus dibiasakannya dengan cara belajar, beserta keseluruhan dari hasil budi dan karyanya itu.

Berdasarkan pemaparan di atas, dakwah hendaklah dikemas dengan baik sehingga mampu menarik mad'u, misalnya dengan mengkompromikan nilai-nilai ajaran Islam dengan nilai-nilai tradisi atau budaya lokal. Menurut Simuh pendekatan kompromi di sini pernah dilakukan oleh para Walisongo dalam penyebaran Islam di tanah Jawa yang sebelumnya memang kental akan nilai-nilai budaya Hindu dan Budha (meskipun tentu ada ajaran-ajaran Islam yang tidak bisa dikompromikan seperti tata cara shalat). Para wali tidak berusaha secara frontal dalam menghadapi masyarakat setempat, tetapi ada strategi budaya yang dikembangkan agar Islam bukan merupakan sesuatu yang asing bagi masyarakat setempat, tetapi merupakan sesuatu yang akrab karena sarana, bahasa dan pendekatan yang dipakai merupakan hal-hal yang sudah dekat dengan seperti selamatan, kenduri, mitoni dan sebagainya. Pendekatan-pendekatan yang kompromis inilah yang melahirkan banyak produk budaya dalam masyarakat, yang tentu saja mengandung ajaran-ajaran di samping seni dan hiburan yang dapat menyampaikan misi Islam yang rahmatan lil alamin. ${ }^{13}$ Sebagaimana firman Allah SWT dalam QS. Al-Hujurat: 13:

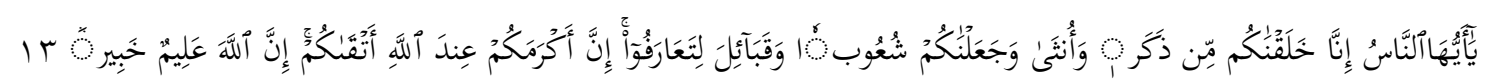

Artinya:"Hai manusia, sesungguhnya Kami menciptakan kamu dari seorang laki-laki dan seorang perempuan dan menjadikan kamu berbangsa-bangsa dan bersuku-suku supaya kamu saling kenal-mengenal. Sesungguhnya orang yang paling mulia di antara kamu di sisi Allah ialah orang yang paling takwa diantara kamu. Sesungguhnya Allah Maha Mengetahui lagi Maha Mengenal." (QS. Al-Hujurat: 13)

\section{Lokasi Penelitian}

\section{A. Gambaran Tempat Yang Akan Diberi Dakwah}

Menurut Kuntjaraningrat di atas, semua pegawai negeri disebut priyayi. Mereka yang bekerja di kantor-kantor pemerintahan disebut priyayi, khususnya di kantor-kantor pemerintahan dalam negeri, seperti kantor kabupaten, kantor kawedanan, kantor kecamatan, kantor Kelurahan, dan sebagainya. Mereka yang bekerja sebagai pegawai di kantor kejaksaan dan kantor pengadilan juga disebut priyayi, bahkan guru-guru sekolah desa dan sekolah dasar pribumi juga disebut priyayi. ${ }^{15}$ Atau sering disebut priyayi rendah/baru (bukan pangrehpraja).

Berdasarkan uraian di atas, tempat yang akan diberi dakwah adalah pegawai pemerintahan Kelurahan Bangetayu Kulon, Kecamatan Genuk. Kelurahan Bangetayu Kulon mempunyai tugas pokok dan fungsi untuk membantu camat Genuk Kota Semarang dalam peneyelenggaraan pemerintahan, pembangunan dan pembinaan kehidupan kemasyarakatan di wilayah kelurahan. ${ }^{16}$ Jumlah total perangkat Kelurahaan ada tujuh orang beragama Islam, adapun susunan Organisasi Kelurahan Bangetayu Kulon Kecamatan Genuk Kota Semarang terdiri dari lima pegawai, yaitu:

\footnotetext{
${ }^{20}$ Sulasman, Teori-Teori Kebudayaan, (Bandung: CV. Pustaka Setia, 2013), 17-19.

13 Aziz Muslim, Dakwah Melalui Pemaknaan Budaya, (Jakarta: Artikel, 2009), 8.

${ }^{14}$ Depag RI, Al-Hidayah (Al-Qur'an Tafsir Per Kata Tajwid Kode Angka), (Jakarta: PT Kalim, 2010), 518.

${ }^{15}$ Sartono Kartodirdjo, dkk, Perkembangan Peradaban Priyayi, 10.

${ }^{16}$ Koetjaraningrat, dkk, Manusia dan Kebudayaan di Indonesia, (Jakarta: Djambatan, 2002), 345.
} 


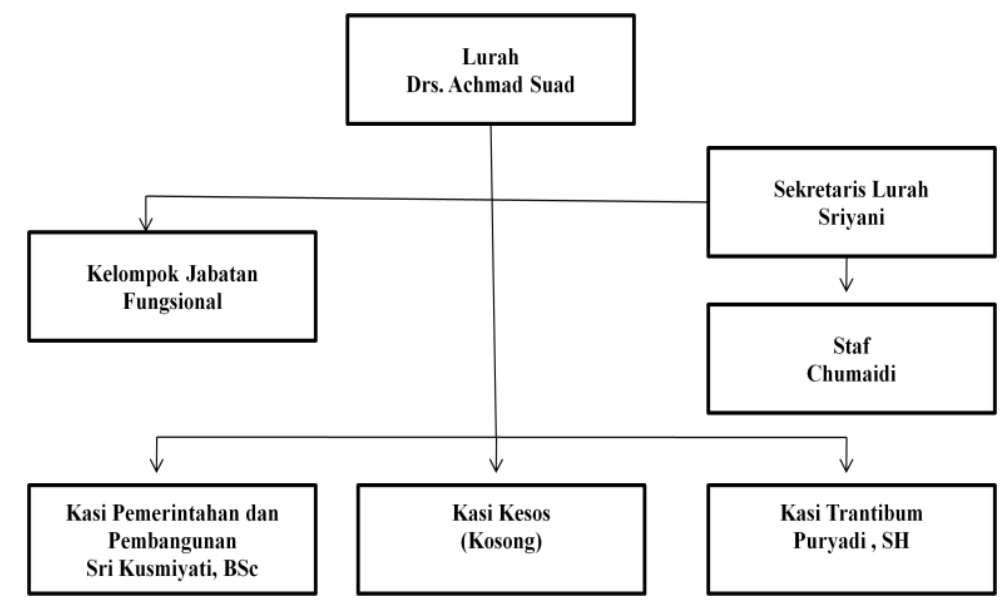

Gambar 1. Struktur Organisasi Kelurahan Bangetayu Kulon, Kecamatan Genuk

Setelah penulis melakukan wawancara, tampak gambaran pegawai pemerintahan sebelum adanya proses dakwah yang harus diperbaiki, yaitu: (1) adanya pegawai wanita yang belum memakai jilbab, (2) belum ada mushola dikarenakan dekat dengan masjid, (3) waktu salat belum bisa berjamaah karena faktor pekerjaan, (4) pegawai pemerintahan terlalu sibuk dengan pekerjaan bahkan tidak ada waktu istirahat, akibatnya salat dan jam makan harus pandai-pandai mencuri waktu, (5) belum ada kekhasan budaya lokal yang nampak di kelurahan.

Sedangkan kegiatan pegawai pemerintahan yang sudah ada dan bernilai positif selama ini, yaitu: (1) adanya bimbingan mental dan kepegawaian dari Kecamatan setiap bulan, (2) adanya kelompok pengajian "An-Nisa" perkecamatan Genuk setiap bulan, (3) adanya tausiyah dari ustadzah Nadziyah setiap akhir bulan hari Jum'at, (4) Adanya pembinaan PKK sebulan sekali, seperti penyuluhan kesehatan, pendidikan, keterampilan, kewirausahaan, dan sebagainya kepada penduduk desa, (5) kelurahan mengerahkan pegawai untuk gugur gunung setiap minggu, (6) untuk mengatasi kesulitan ekonomi di desa didirikan koperasi pertanian, koperasi konsumsi, dan bank desa, (7) etos kerja yang Islami sudah tampak pada pegawai, seperti: pimpinan (lurah) tidak sewenang-wenang pada pegawai, pimpinan dan pegawai datang tepat waktu jam 07.00, tidak ada yang tersandung $\mathrm{KKN}$, tanggungjawab pegawai terhadap pekerjaan baik (pelayanan kantor jam 07.00-15.15 WIB, tetapi jika masyarakat membutuhkan pelayanan lebih bisa telepon), hubungan dengan rekan kerja terjalin harmonis (salam, sapa, senyum), dan sesibuk apapun pekerjaan tidak meninggalkan salat.

\section{Analisis dan Penyajian Data}

\section{A. MODEL DAKWAH}

Ada beberapa model dakwah yang harus direncanakan apabila kita diterjunkan di Kelurahan Bangetayu Kulon, Kecamatan Genuk. Adapun konsep peneliti sebagai berikut:

\section{1) Da'i atau Subjek Dakwah}

Faktor subjek dakwah sangat menentukan keberhasilan aktivitas dakwah. Maka subjek dakwah dalam hal ini da'i atau lembaga dakwah mampu menjadi penggerak dakwah yang profesional. Baik gerakan dakwah yang dilakukan oleh individual maupun kolektif, profesionalisme sangat dibutuhkan, termasuk profesionalisme lembaga-lembaga dakwah. ${ }^{17}$ Adapun konsep peneliti sebagai da'i, yaitu dengan dakwah bil-hikmah mampu membangun etos kerja Islami pada masyarakat priyayi Jawa, pada Kelurahan Bangetayu Kulon, Kecamatan Genuk.

\footnotetext{
${ }^{17}$ Abdurrahman Mad'ud, Rekontruksi Pemikiran Dakwah Islam, (Jakarta: AMZAH, 2008), 26.
} 


\section{2) Materi Dakwah}

Menurut Kamus Besar Bahasa Indonesia, materi adalah benda; bahan; segala sesuatu yang tampak, sesuatu yang menjadi bahan. ${ }^{18}$ Sehingga materi dakwah adalah bahan, pesan yang digunakan dalam menyampaikan pesan-pesan dakwah.Sebelum seorang da'i menyampaikan dakwahnya kepada masyarakat Islam priyayi, seorang da'i harus menentukan materi dan tema yang akan dibicarakan supaya para pendengarnya dapat mengambil manfaat yang nyata dari dakwah yang disampaikannya.

Orang yang mempunyai dan menghayati etos kerja akan tampak dalam sikap dan tingkah lakunya. Ada semacam panggilan hati untuk terus-menerus memperbaiki diri, mencari prestasi, dan tampil sebagai bagian dariumat yang terbaik. Ciri-ciri pribadi yang memiliki etos kerja Islami adalah, (a) kecanduan terhadap waktu, (b) memiliki moralitas yang bersih, (c) kecanduan kejujuran, (d) memiliki komitmen, (e) Istiqamah dan kuat pendirian, (f) kecanduan disiplin, (f) konsekuen dan beranimenghadapi tantangan, (g) memiliki sikap percaya diri, (h) orang yang kreatif, (i) tipe orang yang bertanggungjawab, (j) Bahagia karena melayani, (k) memiliki harga diri, (l) memiliki jiwa kepemimpinan, (m) Berorientasi masa depan, (n) hidup hemat dan efisien, (o) memiliki jiwa wiraswasta, (p) memiliki insting bertanding, (q) keinginan untuk mandiri, (r) kecanduan belajar dan harus mencari ilmu. ${ }^{19}$

Berdasarkan uraian di atas, etos kerja Islami di Kelurahan Bangetayu Kulon, Kecamatan Genuk sudah berjalan baik, terlihat dari pimpinan dan pegawai terjalin hubungan yang sudah baik.

Menurut Bu Sri Kusmiyati, BSc (pegawai kelurahan) mengatakan bahwa "saya bekerja bukan tuntunan ingin dipuji orang lain atau tuntutan pemerintahan. Saya bekerja karena Allah SWT. Apabila saya bekerja dengan baik, seperti tidak KKN, datang tepat waktu, dan sebagainya pasti Allah SWT membalas dengan kebaikan pula. Saya mencoba tanamkan hal itu pada diri saya sendiri."

\section{3) Metode Dakwah}

Menurut Kamus Besar Bahasa Indonesia, metode adalah (1) cara teratur yang digunakan untuk melaksanakan suatu pekerjaan agar tercapai sesuai dengan yang dikehendaki; (2) cara kerja yang bersistem untuk memudahkan pelaksanaan suatu kegiatan guna mencapai tujuan yang ditentukan. ${ }^{20}$ Sehingga metode dakwah adalah cara yang digunakan dalam menyampaikan pesan-pesan dakwah.

Masyarakat priyayi pada pegawai pemerintahan Kelurahan Bangetayu Kulon, Kecamatan Genuk merupakan lapisan atas dalam masyarakat.Masyarakat priyayi terdiri dari masyarakat intelektual dari berbagai disiplin ilmu. Adapun analisis penulis tentang konsep metode yang tepat yaitu, berdasarkan dalil al-Qur'an Surat An-Nahl: 125 terdapat tiga metode dakwah yaitu: (1) hikmah (dengan kebijaksanaan), (2) mau'izhah hasanah (nasihat-nasihat yang baik), dan (3) mujadalah bil lati hiya ahsan (diskusi dengan cara yang baik). ${ }^{21}$ Di antara ketiga metode tersebut, peneliti lebih fokus pada dakwah bil-hikmah.

Dakwah bil hikmah yang berarti dakwah bijak, mempunyai makna selalu memperhatikan suasana, situasi, dan kondisi mad'u (muqtadha al-hal). Hal ini berarti menggunakan metode relevan dan realistis sebagai tantangan dan kebutuhan, dengan memperhatikan kadar pemikiran dan intelektual, suasana psikologis, serta situasi sosial kultural.

Menurut Sayid Qutb, ${ }^{22}$ dakwah dengan metode hikmah akan terwujud apabila memperhatikan tiga faktor, pertama, keadaan dan situasi orang-orang yang didakwahi. Kedua, kadar atau ukuran

\footnotetext{
18 Anonim, "Materi”, diakses 15 Maret 2017, http: //kamusbahasaindonesia. org/.

${ }^{19}$ Muhamad Nafik Hadi Ryandono, Etos Kerja $\quad$ Islami Pada Pedagang Muslim Pasar Besar Kota Madiun, dalam jurnal JESTT Vol. 2 No. 4 April 2015, 278-279.

20 Anonim, "Metode”, diakses 15 Maret 2017, http: //kamusbahasaindonesia. org/.

${ }^{21}$ Acep Aripudin, Pengembangan Metode Dakwah, (Jakarta: PT. RajaGrafindo Persada, 2011), 65-173.

${ }^{22}$ Asep Muhyidin, Metode Pengembangan Dakwah, 79-80.
} 
materi dakwah yang disampaikan agar mereka merasa tidak keberatan dengan beban materi tersebut. Ketiga, metode penyampaian materi dakwah dengan membuat variasi sedemikian rupa yang sesuai dengan kondisi pada saat itu.

Metode dakwah tidak cukup mempergunakan metode tradisional (bil-lisan), melainkan perlu diterapkan penggunaan metode bil-hal (dakwah dengan amal nyata, keteladanan). Menurut peneliti keteladanan yang inovatif datangnya berawal dari pimpinan. Pimpinan memberikan keteladanan yang baik maka pegawai pun akan bekerja dengan baik. Sehingga budaya etos kerja Islami dapat berjalan dengan harmonis. ${ }^{23}$

Metode Bil-Hikmah menurut peneliti lebih cocok untuk masyarakat priyayi Jawa karena prinsip metode dakwah bil-hikmah ditujukan terhadap mad'u yang kapasitas intelektual pemikirannya terkategorisasikan khawas, cendikiawan, atau ilmuwan. Sedangkan Mau'izhah Hasanah, prinsip metode ini diarahkan terhadap mad'u yang kapasitas intelektual dan pemikiran serta pengalaman spiritualnya tergolong kelompok awam. Mujadalah bil lati hiya ahsan, prinsip metode ini ditujukan sebagai reaksi alternatif dalam menjawab tantangan respon negatif dari mad'u, khususnya bagi sasaran yang menolak, tidak peduli, atau bahkan melecehkan seruan. ${ }^{24}$

\section{4) Media Dakwah}

Menurut Kamus Besar Bahasa Indonesia, media adalah (1) alat; (2) alat (sarana) komunikasi seperti koran, majalah, radio, televisi, film, poster, dan spanduk. ${ }^{25}$ Sehingga media dakwah adalah alat (sarana) yang digunakan dalam menyampaikan pesan-pesan dakwah.

Sarana dalam meningkatkan etos kerja Islami pegawai pemerintahan di Kelurahan Bangetayu Kulon, Kecamatan Genuk, salah satunya melalui sarana pendidikan seperti, (1) majlis taklim, (2) mengkader pimpinan yang anti-korupsi, (3) menciptakan sistem kerja yang Islami sesuai ajaran Islam. $^{26}$

\section{5) Mad'u atau Objek dakwah}

Klasifikasi objek dakwah adalah kelompok orang kaum elit/priyayi. Mad'u yang memiliki kapasitas intelektual pemikirannya terkategorisasikan khawas, cendekiawan, atau ilmuwan. Priyayi di sini adalah orang yang mengerjakan pekerjaan halus yakni yang bekerja pada pemerintahan, salah satunya pegawai pemerintahan Kelurahan Bangetayu Kulon, Kecamatan Genuk.

\section{Kesimpulan}

Dakwah menempati posisi yang tinggi dan mulia dalam kemajuan agama Islam, karena dakwah bertujuan untuk membuka potensi manusia agar eksistensi mereka punya makna di hadapan Tuhan dan sejarah. Dalam berdakwah harus memperhatikan budaya dan psikologis warga setempat. Salah satunya, dakwah dilakukan dengan bil-hikmah (bijaksana).

Dakwah bil-hikmah dalam membangun etos kerja Islami pada masyarakat priyayi Jawa (Pegawai Pemerintahan Kelurahan Bangetayu Kulon, Kecamatan Genuk) di atas diharapkan dapat berdampak positif. Sasaran dakwah peneliti pertama pada pimpinan (lurah), kemudian pada pegawai pemerintahan. Keteladanan pimpinan yang baik sebagai modal awal dalam membangun etos kerja Islami.Seorang da'i hendaknya melakukan riset terlebih dahulu sebelum diterjunkan ke lapangan. Salah satunya dengan membuat model dakwah (da'i, materi, metode, media, mad'u) yang inovatif.

\footnotetext{
${ }^{23}$ Abdurrahman Mad'ud, Rekontruksi Pemikiran Dakwah Islam, 178-179.

${ }^{24}$ Asep Muhyidin, Metode Pengembangan Dakwah, 78-83.

25 Anonim, "Media", diakses 15 Maret 2017, http: //kamusbahasaindonesia. org/.

${ }^{26}$ Azyumardi Azra, Pengembangan Metode Dakwah, (Jakarta: PT. RajaGrafindo Persada, 2011), 13.
} 


\section{DAFTAR PUSTAKA}

Aripudin, Acep. 2011. Pengembangan Metode Dakwah. Jakarta: PT. RajaGrafindo Persada.

Aripudin, Acep. 2012. Dakwah Antarbudaya. Bandung: PT. Remaja Rosdakarya.

Azra, Azyumardi. 2011. Pengembangan Metode Dakwah. Jakarta: PT. RajaGrafindo Persada.

Depag. 2013. Al-Qur'anul Karim. Jakarta: PT. Indah Kiat Pulp \& Paper Tbk

Departemen Agama Republik Indonesia. 2012. Al-Qur'an dan Terjemahannya. Jakarta: Karya Insan Indonesia.

Kartodirdjo, Sartono, dkk. 1987. Perkembangan Peradaban Priyayi. Yogyakarta: Gadjah Mada University Press.

Koetjaraningrat, dkk. 2002. Manusia dan Kebudayaan di Indonesia. Jakarta: Djambatan

Mad'ud, Abdurrahman. 2008. Rekontruksi Pemikiran Dakwah Islam. Jakarta: AMZAH.

Mooduto, Arie. 2012. Ekonomi Islam: Pilihan Mutlak Seorang Muslim. Jakarta.

Muslim, Aziz. 2009. Dakwah Melalui Pemaknaan Budaya. Jakarta: Artikel.

Rangkuti, Freddy. 2012. Keajaiban Teknik Selling Rasulullah. Jakarta: Gramedia Pustaka Utama.

Scherer, Savitri. 2012. Keselarasan \& Kejanggalan (Pemikiran-Pemikiran Priyayi Nasionalis Jawa Awal Abad XX). Jakarta: Komunitas Bambu.

Sulasman. 2013. Teori-Teori Kebudayaan. Bandung: CV. Pustaka Setia.

Anonim, Rencana Program Kerja Tahunan Kelurahan Tahun Anggaran 2016 Kelurahan Bangetayu Kulon Kecamatan Genuk, dalam laporan 2016.

Ilahi, Mohammad Takdir "Konfigurasi Islam Nusantara: dari Islam Santri, Abangan, hingga Priyayi," diakses pada Sabtu, 7 Mei 2016, http://www.nu.or.id/post/read/67961/konfigurasiislam-nusantara-dari-islam-santri-abangan-hingga-priyayi.

Nugroho, Mahendra Dwi Satrio, dkk, “ Makna Pemakaian Gelar Kebangsawanan Jawa (Sebuah Interpretative Phenomenological Analysis)”, Jurnal Empati, Agustus 2016, Volume 5(3).

Ryandono, Muhamad Nafik Hadi, Etos Kerja Islami Pada Kinerja BisnisPedagang Muslim Pasar Besar Kota Madiun, dalam jurnal JESTT Vol. 2 No. 4 April 2015.

Widiatiaga, Bima, "Resume Abangan, Santri, dan Priyayi dalam Masyarakat Jawa, Karya Clifford Geertz, " dalam resume, UNS Surakarta, 2014. 